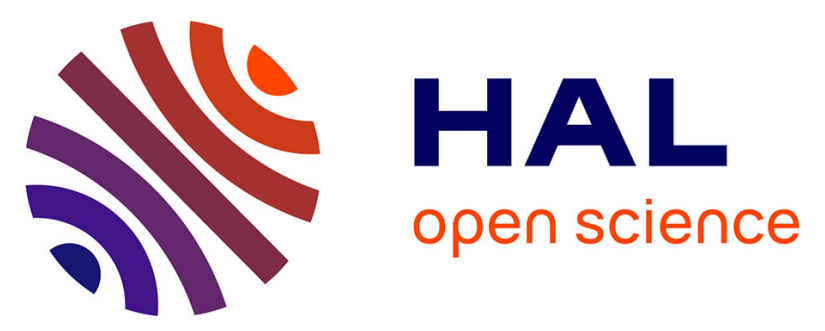

\title{
Lava effusion - A slow fuse for paroxysms at Stromboli volcano?
}

S. Calvari, L. Spampinato, A. Bonaccorso, Clive Oppenheimer, E. Rivalta, E. Boschi

\section{- To cite this version:}

S. Calvari, L. Spampinato, A. Bonaccorso, Clive Oppenheimer, E. Rivalta, et al.. Lava effusion - A slow fuse for paroxysms at Stromboli volcano?. Earth and Planetary Science Letters, 2011, 301 (1-2), pp.317-323. 10.1016/j.epsl.2010.11.015 . insu-00544589

\section{HAL Id: insu-00544589 \\ https://hal-insu.archives-ouvertes.fr/insu-00544589}

Submitted on 19 Jan 2011

HAL is a multi-disciplinary open access archive for the deposit and dissemination of scientific research documents, whether they are published or not. The documents may come from teaching and research institutions in France or abroad, or from public or private research centers.
L'archive ouverte pluridisciplinaire HAL, est destinée au dépôt et à la diffusion de documents scientifiques de niveau recherche, publiés ou non, émanant des établissements d'enseignement et de recherche français ou étrangers, des laboratoires publics ou privés. 


\section{Lava effusion - A slow fuse for paroxysms at Stromboli volcano?}

\section{S. Calvaria, L Spampinatoa, $\underline{\text { b }}$, A. Bonac corsoạ, C. Oppenheimer $\underline{b}$, c, E. Rivaltad and E. Boschia}

a Istituto Nazionale di Geofisica e Vulcanologia, sezione di Catania, Piazza Roma 2, 95123 Catania, Italy

b Department of Geography, University of Cambridge, United Kingdom

c Institut des Sciences de la Terre d'Orléans, la rue de la Férollerie, 45071 Orléans, cedex 2, France

a School of Earth and Environment, 15-19 Hyde Terrace, University of Leeds, Leeds LS2 9JT, UK

\section{Abstract}

The 2007 effusive eruption of Stromboli followed a similar pattern to the previous 2002-2003 episode. In both cases, magma ascent led to breaching of the uppermost part of the conduit forming an eruptive fissure that discharged lava down the Sciara del Fuoco depression. Both eruptions also displayed a 'paroxysmal' explosive event during lava flow output. From daily effusion rate measurements retrieved from helicopter- and satellite-based infrared imaging, we deduce that the cumulative volume of lava erupted before each of the two paroxysms was similar. Based on this finding, we propose a conceptual model to explain why both paroxysms occurred after this 'threshold' cumulative volume of magma was erupted. The gradual decompression of the deep plumbing system induced by magma withdrawal and eruption, drew deeper volatile-rich magma into the conduit, leading to the paroxysms. The proposed model might provide a basis for forecasting paroxysmal explosions during future effusive eruptions of Stromboli.

Keywords: Stromboli volcano; effusive eruptions; paroxysmal explosions; paroxysm prediction

\section{Introduction}

Stromboli volcano has been almost continuously active for $1300 \mathrm{yr}$ ([Giberti ef al., 1992] and [Rosi et al., 2000]). The steady supply of magma is associated with a bi-flow regime in the conduit, sustained degassing and frequent Strombolian eruptions (sensu strictu), punctuated roughly every 4 to 5 yr by much stronger explosions, commonly referred to as paroxysms (Barberi et al., 1993). These explosions erupt the same highly porphyritic (HP), high-density, crystallised magma associated with typical Strombolian activity and residing 
within the conduit but mixed with variable amounts ([Lautze and Houghton, 2007] and [Polacci et al., 2009]) of less-porphyritic (LP), low-density, volatilerich magma ascending directly from an intermediate storage zone (at 6-9 km depth (Fig. 1; [Di Carlo et al., 2006], [Métrich et al., 2005] and [Pichavant et al., 2009]). Once injected into the conduit system, this LP magma rises rapidly enough to inhibit crystallisation and gas separation, resulting in limited mixing with HP magma. Paroxysms produce dense plumes that rise $3-4 \mathrm{~km}$ above the crater, and almost all of them have had an impact on the settled area ([Calvari et al., 2006], [Calvari et al., 2010] and [Rittmann, 1931]). On a small island $\sim 4 \mathrm{~km}$ wide and $1 \mathrm{~km}$ high, and populated during summer by as many as 6000 people, such events represent a significant hazard; several people were killed as a result of paroxysms in 1919 and 1930 (Rittmann, 1931). Predicting the occurrence of paroxysms thus assumes considerable importance from a civil protection perspective.

At least two patterns of behaviour have been recognised for Stromboli's historic activity: (i) paroxysms followed by lava effusion, and (ii) lava effusion followed by paroxysms ([Barberi et al., 1993] and [Perret, 1916]). Lava effusions at Stromboli are fairly common - they occur on average every $3.7 \mathrm{yr}$ (Barberi et al., 1993). The last two episodes occurred in 2002-2003 ([Bonaccorso et al., 2003], [Calvari et al., 2005a] and [Calvari et al., 2005b]) and 2007 (Calvari et al., 2010). Both were associated with paroxysms ([Calvari et al., 2006], [Calvari et al., 2010] and [Harris et al., 2008]) that occurred once lava effusion was underway, thus conforming to case (ii) as described above. Depressurisation of deeper regions of the magma supply system, resulting in exsolution (primarily of $\mathrm{CO}_{2}$ ) and rapid ascent of a buoyant batch of LP magma, is one of the mechanisms invoked to explain Stromboli's paroxysms (e.g., Aiuppa et al., 2009).

(Alidibirov and Panov, 1998), (Martel et al., 2000) and (Ichihara et al., 2002) support the general idea that decompression rate is one of the key variables influencing eruptive style of eruption, with faster decompression rates inducing fragmentation. However, the two most recent Stromboli paroxysms appear to be associated with slow decompression, because the depressurisation and lava effusion took place over a period of days/weeks. Here, we develop this hypothesis further through an analysis of effusion rate data from the 2002-2003 ([Calvari et al., 2005a], [Calvari et al., 2005b], [Harris et al., 2005] and [Lodato et al., 2007]) and 2007 eruptions (Calvari et al., 2010). We evaluate these observations in the light of studies and laboratory experiments and propose a triggering mechanism for paroxysms that occur during basaltic effusive eruptions. Our hypothesis was developed during the 2007 eruption because its similarity to the 2002-2003 eruption led us to anticipate the 15 March paroxysm. The new model might be the key to understanding how the shallow supply system works, and because it is linked to surface observations of lava effusion, and thus to erupted lava volumes, it could pave the way to forecasting of future paroxysms. 


\section{Recent paroxysms and effusive enuptions}

Table 1 summarises paroxysms that occurred over the last century. Although this provides a valuable longer timeframe over which to consider the coincidence of effusive and paroxysmal events, eruption parameters including magnitude and column height cannot be systematically determined in most of the cases, and sometimes not at all. This is why we focus on the 2002-2003 and 2007 effusive episodes, for which we have reliable geophysical and volcanological data. The following summarises the key events from available accounts ([Bonaccorso et al., 2003], [Burton et al., 2008], [Calvari et al., 2005a], [Calvari et al., 2005b], [Calvari et al., 2006], [Calvari et al., 2010], [Harris et al., 2008], [Lodato et al., 2007], [Neri and Lanzafame, 2009] and [Spampinato et al., 2008]).

The 2002-2003 eruption began on 28 December, after about seven months of accentuated Strombolian activity at the summit craters during which the frequency of explosions and height of ejecta had both increased. On 28 December, a NE-trending fissure opened at $500 \mathrm{~m}$ a.s.l. on the northern flank of the summit crater (Fig. 2a), sourcing lava flows that resulted in complete drainage of the craters and cessation of the typical explosive activity (Fig. 2a). On 5 April, while lava was still erupting, the obstructed summit craters of the volcano were the site of one of the strongest paroxysms recorded at Stromboli since 1930 (Rittmann, 1931). The effusive eruption ended between 21 and 22 July, after the expulsion of an estimated total of $\sim 13 \times 10^{6} \mathrm{~m}^{3}$ of vesiculated lava ([Calvari et al., 2005a] and [Calvari et al., 2005b]). A similar amount of $11.5 \times 10^{6} \mathrm{~m}^{3}$ was estimated by using high precision photogrammetry (Baldi et al., 2008), though this figure excludes any lava emplaced below sea level.

The 2007 eruption began on 27 February, after several months of intense explosive activity at the summit craters, with two eruptive fissures propagating on the NE flank of the summit cone (Fig. 2b). Explosive activity ceased as soon as the NE summit cone was breached, and a vent opened at the eastern margin on the Sciara del Fuoco at $\sim 400 \mathrm{~m}$ a.s.l. (Fig. 2b). More than half of the erupted volume of lava was emplaced during the first 5.5 days, with a peak discharge rate that was one order of magnitude greater than the 20022003 eruption. On 15 March 2007, while lava effusion was continuing, a paroxysmal explosion occurred at the summit, with similar features to the 5 April 2003 event. Both events occurred during lava output, when the summit craters were obstructed by debris derived from the crater walls. Lava continued pouring out but at a diminishing rate until 2 April, when the eruption ceased. Estimates of the erupted volume range between $\sim 7.1 \pm 3.9 \times 10^{6} \mathrm{~m}^{3}$ (Calvari et al., 2010) and $\sim 8.9 \pm 1.5 \times 10^{6} \mathrm{~m}^{3}$ (Neri and Lanzafame, 2009). Both these figures were calculated from analysis of thermal imagery, and represent dense rock equivalent volumes (DRE; [Harris et al., 2005] and [Harris et al., 2007]). To compare them with the 2002-2003 bulk volumes requires accounting for the average vesicularity. Vesicularity of the 
2002-2003 lavas was found to be between 16 and 32\% (Fornaciai et al., 2009). Using these values, the 2002-2003 DRE volume was $\sim 9.9 \pm 2.0 \times 10^{6} \mathrm{~m}^{3}$ based on the estimate of (Calvari et al., 2005a) and (Calvari et al., 2005b), comparable with the $8.7 \pm 1.8 \times 10^{6} \mathrm{~m}^{3}$ derived by photogrammetry (Baldi et al., 2008). To avoid complications arising from uncertainties in vesicularity, in the following analysis we use the effusion rate data derived from thermal imagery acquired from satellite and airborne platforms ([Calvari et al., 2005a], [Calvari et al., 2005b], [Calvari et al., 2010], [Harris et al., 2005] and [Lodato et al., 2007]). These yield time-series of the cumulative volumes erupted before both 2003 and 2007 paroxysms.

\section{Effusion rates and enupted volumes}

Effusion rate is a crucial parameter when monitoring effusive eruptions since it controls the extension, morphology and shape of a lava flow field (e.g., [Calvari and Pinkerton, 1998], [Harris et al., 2007], [Kilburn, 1993], [Killburn and Lopes, 1988], [Lombardo et al., 2009] and [Walker, 1973]). Thus, timely and at least daily effusion rate measurements are essential in support of lava flow monitoring and hazard mitigation. Daily effusion rates measured during ongoing eruptions allow continuous update of the erupted volume, revealing processes occurring in the magma plumbing system. Only for the last two (2002-2003 and 2007) Stromboli effusive eruptions do we have fairly detailed data sets of effusion rates.

Thermal surveys from a helicopter were carried out using a hand-held infrared camera. Using the model of Harris et al. (2005), thermal imagery from both satellite-borne instruments and the helicopter-based survey were used to estimate the minimum and maximum daily effusion rates. Error budgets for the effusion rates are comparable for both the helicopter surveys and satellite imagery ( \pm 40\%, [Calvari et al., 2005a] and [Calvari et al., 2005b]).

Figure 3 reports the daily maximum effusion rate data merged together to provide a complete set of daily cumulative maximum volume for the entire durations of the two eruptions. Although the 2002-2003 effusive eruption lasted five months longer than the 2007 event, the latter was characterised by a higher initial effusion rate. Calvari et al., 2005a S. Calvari, L. Spampinato, L. Lodato, A.J.L. Harris, M.R. Patrick, J. Dehn, M.R. Burton and D. Andronico, Chronology and complex volcanic processes during the 2002-2003 flank eruption at Stromboli volcano (Italy) reconstructed from direct observations and surveys with a hand-held thermal camera, J. Geophys. Res. 110 (2005), p. B02201 (Calvari et al., 2005a), (Calvari et al., 2005b), (Lodato et al., 2007) and (Calvari et al., 2010) calculated mean effusion rates of $0.5 \mathrm{~m}^{3} \mathrm{~s}^{-1}$ (for a 156 day emplacement time) and $1.5 \mathrm{~m}^{3} \mathrm{~s}^{-1}$ (considering a 34 day emplacement time) for the 2002-2003 and 2007 effusive eruptions, respectively. 
From Figure 3, we derived the DRE cumulative volumes erupted before both paroxysms (Fig. 4). Figure 4 shows the complete time-series of cumulative volume of erupted lava for the two eruptions. It reveals the key result emerging from this analysis that, prior to each paroxysm, similar amounts of lava were erupted (green triangles in Fig. 4), i.e. $\sim 4.4$ and $4.2 \times 10^{6} \mathrm{~m}^{3}$ for the 5 April 2003 and 15 March 2007 paroxysms, respectively. This suggests also that the volume of the drained upper feeder system is comparable. Our hypothesis is that this coincidence reflects a common triggering process for the paroxysms.

\section{Decompression and enuptive regime}

Models of magma transport in volcanic conduits (e.g., [Jaupart and Vergniolle, 1988] and [Wilson, 1980]) describe the fluid dynamics involved in a wide range of eruptive styles, and offer both conceptual and quantitative insights into the nature of mild explosive basaltic activity, such as Strombolian or Hawaiian. The reasons for the sudden switch from effusive to explosive activity associated with paroxysms, and their association with conduit drainage remain enigmatic. At Stromboli, paroxysms appear to be caused by some processes distinct from those controlling the persistent Strombolian activity. In fact, paroxysms are characterised by eruption of LP magma, and by significantly higher eruption intensity (e.g. [Andronico and Pistolesi, 2010], [Bertagnini et al., 1999] and [Calvari et al., 2006]).

Considering the 2002-2003 and 2007 eruptions, if a similar plumbing system geometry is postulated, then the effusion of a similar amount of magma before paroxysms suggests a comparable decompression of the deep feeding system. In this context, LP magma, slowly ascending and taking the place of the erupted HP magma at shallower levels, reached at some point a critical depth level inducing mass vesiculation. Namiki and Manga (2006) proposed a mechanism that could potentially trigger basaltic explosive behaviour, based on an investigation of the expansion of low viscosity bubbly fluids experiencing decompression at variable rates. They observed experimentally the importance of decompression rate in the expansion behaviour of a bubbly fluid, and compared their observation with velocities of expansion calculated under 'equilibrium' conditions (i.e. when the gas expands within the bubbles keeping pace with decompression rate), and in case of non-equilibrium (i.e. when decompression rate exceeds the bubbles' ability to expand). In the latter case, they assume that the enthalpy change due to decompression is transformed into kinetic energy of the expanding bubbly fluid. They compared the two theoretical velocities and integrated the resulting inequality with results from Spieler et al. (2004), who experimentally derived a vesiculation threshold for fragmentation. In this way, they obtained a criterion for the explosive behaviour of basaltic magma: above a critical decompression rate, the non-equilibrium expansion velocity exceeds the equilibrium one, and the regime is predicted to become explosive. The threshold in decompression rate is expressed in terms of vesicularity, initial 
pressure, total decompression (and thus the total erupted lava volume before paroxysms), and height of the bubbly column:

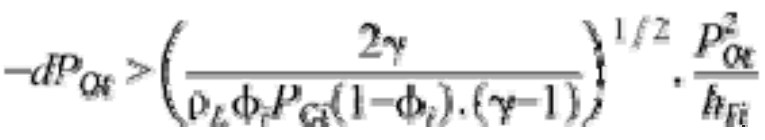

where - $d P_{O}$ is the decompression rate for the disequilibrium expansion in magmas, $\rho_{L}$ is the magma density, $\Phi_{i}$ the vesicularity, $P_{G i}$ the initial pressure of the gas inside the bubbles, $P_{0 t}$ the pressure of the gas outside the bubbles during the expansion, $y$ the isentropic exponent, and $h_{F i}$ the height of the bubbly magma column. In the context of Stromboli volcano, we assume that the bubbly magma column is represented by just LP magma, given that the HP magma fills only the upper portion of the feeder conduit (Fig. 5).

A key point is that the threshold in decompression rate is inversely proportional to the height of the bubbly magma column, meaning that a higher column of bubbly magma will experience disequilibrium expansion at lower decompression rates. This result suggests a scenario that could be applicable to the 2003 and 2007 paroxysms at Stromboli. Figure 6 illustrates Eq. 21 in Namiki and Manga (2006) or Eq. (1) here, using parameters appropriate for Stromboli as reported in the caption of Figure 6. As decompression due to lava effusion promotes exsolution over greater depth levels, the column of LP magma would slowly extend in height, potentially leading to a sudden transition from effusive to explosive regimes (Fig. 6).

\section{Disc ussion}

Fast decompression is recognised as an important trigger for explosive eruptions (e.g. [Alidibirov and Dingwell, 1996] and [Namiki and Manga, 2006]), thus, examples of gradual/slow decompression leading to violent explosion, such as the several days/weeks in the case of Stromboli, have not been widely reported. They may be more widespread than realised, however. For instance, paroxysms of comparable magnitude to Stromboli's have been observed at Fuego in Guatemala (Lyons et al., 2010) and Vesuvius in 1944 (Hazlett et al., 1991), where paroxysms consistently followed the onset of effusive eruptions.

The similarities between the 2002-2003 and 2007 effusive eruptions at Stromboli volcano, and the occurrence of paroxysmal explosions during lava flow output in each case, suggest similar triggering mechanisms for both paroxysms. In fact, the 15 March 2007 explosive event was foreseen on the basis of the 2002-2003 experience, i.e. that a threshold volume of erupted lava, reflecting a threshold of decompression needed to be discharged from the supply system before LP magma could reach the surface in a paroxysm. If this is true, it is crucial that this threshold volume of erupted magma is discharged at a rate exceeding the LP magma crystallisation rate, thus 
avoiding LP-HP magma mixing or LP magma transition to HP producing only the typical Strombolian activity ([Burton et al., 2007] and [Schiavi et al., 2010]). Thus, it is striking that both 2003 and 2007 paroxysms ensued on discharge of comparable DRE volumes of magma $\left(\sim 4.0 \times 10^{6} \mathrm{~m}^{3}\right)$, implying that paroxysmal events can occur after the start of an apparently gentle effusive eruption. That eruption of such a magma volume could be enough to destabilize the LP magma likely reflects the volume of HP magma stored above the LP source region ([Bertagnini et al., 2003], [Francalanci et al., 2005] and [Métrich et al., 2005]). Applying the model for Stromboli's conduit of (Bonaccorso and Davis, 1999) and (Genco and Ripepe, 2010) estimated a conduit radius of $5 \mathrm{~m}$ by modelling of the tilt recorded during the volcano ordinary Strombolian activity. However, considering the model of Burton et al. (2009) for magma circulation and HP magma recycling within the volcano conduit during effusive phases, conduit effective diameter can vary, i.e. increases, due to HP magma removal for drainage through the eruptive vents. The removal has the effect of increasing the diameter of the conduit available to ascending magma, i.e., in our case, the LP magma. Hence, if we consider a LP storage zone at 6-9 km deep ([Bertagnini et al., 2003], [Métrich et al., 2005] and [Pichavant et al., 2009]), and assume a cylindrical enlarged upper conduit (Burton et al., 2009) with an average radius of $\sim 10 \mathrm{~m}$, the threshold volume of $\sim 4.0 \times 10^{6} \mathrm{~m}^{3}$ represents a significant portion of the magma above the deep LP magma storage zone. After eruption of most of the HP magma stored above the LP storage zone, LP magma ascends to near the surface where it decompresses explosively. This is confirmed by the composition of lavas erupted after the second half of March (Landi et al.., 2009), that can be explained by minor mixing between the LP magma rising through the upper magmatic system during the 15 March paroxysm and the relatively degassed residing HP magma.

However, depressurization of the supply system before the paroxysms occurred progressively. Both 2002-2003 and 2007 eruptions started with abrupt draining of a small "plug", made of HP magma and solid rock as the $\mathrm{NE}$ cone was breached (Fig. 4b-c), allowing conduit magma to drain from the eruptive fissures. This breaching lowered the top of the magma column by 200-300 m (Fig. 4C), decompressing both the upper conduit (0.8-2 km depth, Fig. 1) and, as evidenced by ground deformation observations (Bonaccorso et al., 2008), the vertically-extended intermediate storage zone, located between 2 and $4 \mathrm{~km}$ depth (Fig. 1). The intermediate reservoir connects the LP magma storage zone (tapped by the paroxysms and extending below $4 \mathrm{~km}$ depth; [Bertagnini et al., 2003] and [Métrich et al., 2005]) with the upper conduit (Fig. 1), where expanding gas slugs drive the persistent Strombolian activity (Burton et al., 2007).

In both 2002-2003 and 2007, the conduit breaching corresponds to near instantaneous pressure drop of $\sim 4-6 \mathrm{MPa}$, disturbing the magmastatic equilibrium and promoting lava effusion. Days/weeks after breaching, further drainage of lava occurred via vents that opened along the Sciara del Fuoco, 
enhancing the depressurization of the shallow plumbing system. The estimated DRE effusion rates of $\sim 0.5$ and $1.5 \mathrm{~m}^{3} \mathrm{~s}^{-1}$ prior to both paroxysms exceeded the characteristic magma supply rate to the conduits ( $0.23 \mathrm{~m}^{3} \mathrm{~s}^{-1}$ DRE from Burton et al., 2007), reflecting a significant perturbation of the plumbing system. This is consistent with a significant increase of the $\mathrm{SO}_{2}$ flux from the long-term average value of 150$200 \mathrm{Mg} \mathrm{day}^{-1}$ to $\sim 620 \mathrm{Mg} \mathrm{day}^{-1}$ during the 2007 eruption (Burton et al., 2009). Similarly, the $\mathrm{CO}_{2} / \mathrm{SO}_{2}$ ratio increased from an average of $\sim 4.3$ for the period January-November 2006 to 21 during the effusive eruption (Aiuppa et al., 2009). This was interpreted as the result of an increased contribution of volatiles from the intermediate-deep storage region (Aiuppa et al., 2009) to the upper conduit. Thus, the shallow storage zone can release more volatiles when it is filled by gas-rich magma from deeper levels, implying lengthening of the LP magma bubbly column.

Pichavant et al. (2009), carried out high-pressure laboratory experiments on Stromboli basalts in presence of fluids and found that even the typical Strombolian explosions must include a component of fluids sourced from 150 to $200 \mathrm{MPa}$, corresponding to depths of $\sim 6-9 \mathrm{~km}$, i.e. to the LP deep storage region (Fig. 1). Thus, it is plausible that this region was increasingly tapped for volatiles during the effusive eruptions of 2002-2003 and 2007. We suggest that magma withdrawal from the intermediate magma storage zone by the effusive eruptions led progressively to decompression of the deep LP storage magma in a manner analogous to that described for Kilavea, where decompression of the summit magma chamber due to a diking event, resulted in exsolution of volatiles and an increased gas flux observed at the surface (Poland et al., 2009). In the case of Stromboli, this behaviour promoted by the ascent of volatile-rich LP magma, produced lengthening of the magma bubbly column, favouring disequilibrium expansion.

Considering that in 2003 and 2007 the paroxysms at Stromboli occurred after eruption of $\sim 4 \times 10^{6} \mathrm{~m}^{3}$ of magma, we propose that this cumulative volume might be the threshold corresponding to the critical decompression of the supply system allowing magma fragmentation. Withdrawal of this threshold magma volume tapped a small batch of LP magma which then ascended the conduit. The timescale of its transport to the surface could only have been from hours to days ([Calvari et al., 2006], [Calvari et al., 2010], [Harris et al., 2008] and [Polacci et al., 2009]). The volumes involved in the paroxysms, i.e. $\ll 10^{6} \mathrm{~m}^{3}$ (Bertagnini et al., 1999), reflect the critical balance between magma storage, crystallisation, degassing, and pressure evolution. Furthermore, the fact that the threshold erupted volume required to trigger paroxysms in both 2003 and 2007 was similar suggests that the geometry and capacity of the upper conduit and intermediate storage system varied little over this period.

The 2002-2003 and 2007 cases show that the incubation time for a paroxysm depends on the effusion rate. In 2003, a mean eruption rate of $0.5 \mathrm{~m}^{3} \mathrm{~s}^{-1}$ 
([Calvari et al., 2005a], [Calvari et al., 2005b] and [Lodato et al., 2007]) resulted in a paroxysm after $\sim 3$ months of lava effusion, whereas a mean eruption rate of $1.5 \mathrm{~m}^{3} \mathrm{~s}^{-1}$ in 2007 (Calvari et al., 2010) produced a paroxysm after only two weeks. So long as the volcano maintains its present subsurface storage configuration, we infer that it will be possible to use the same threshold volume to forecast future explosive paroxysmal events.

\section{Concluding remarks}

Analysis of the 2002-2003 and 2007 eruptive episodes on Stromboli suggests that paroxysms can be triggered as a result of the progressive decompression of the conduit system. That a similar quantity of dense lava - approximately $4 \times 10^{6} \mathrm{~m}^{3}$ - was erupted prior to paroxysm in each case hints at the operation of a threshold mechanism. We have argued here that the lava effusion slowly decompresses the magma supply system, acting to extend the depth of the bubbly magma column in the conduit. This promotes fragmentation of the LP magma that has been tapped by the conduit system from its storage zone at 6-9 $\mathrm{km}$ depth. Provided the magmatic system is relatively stable in terms of geometry, magma composition, and supply rate (and Stromboli has demonstrated a high degree of stability over two millennia; Rosi et al., 2000), the timing of paroxysms may be estimated on the basis of daily effusion rate measurements. The use of this threshold during future effusive eruptions at Stromboli could represent a significant step forward in predicting paroxysmal events and prove decisive for civil protection purposes. The slow decompression mechanism and similar threshold criteria may also be relevant to other volcanoes that experience episodes of Strombolian eruption, lava effusion and paroxysms.

\section{Acknowledgements}

This paper was partially supported by a research project (Project INGV-DPC Paroxysm V2/03, 2007-2009) funded by the Istituto Nazionale di Geofisica e Vulcanologia and by the Italian Civil Protection. Comments by S. Lane, M. Patrick, C.R.J. Kilburn and two anonymous reviewers significantly improved an earlier version of the manuscript. E.R. thanks Rafal Dunin-Borkowski, director of Cen/DTU (Denmark), for logistic support.

\section{References}

Aiuppa et al., 2009 A. Aiuppa, C. Federico, C. Giudice, G. Giuffrida, R. Guida S. Guerrieri, M. Liuzzo, R. Moretti and P. Papale, The 2007 eruption of Stromboli volcano: insights from real-time measurement of the volcanic gas plume $\mathrm{CO}_{2} / \mathrm{SO}_{2}$ ratio, J. Volcanol. Geotherm. Res. 182 (2009), pp. 221-230. 
Alidibirov and Dingwell, 1996 M. Alidibirov and D.B. Dingwell, Magma fragmentation by rapid decompression, Nature $\mathbf{3 8 0}$ (1996), pp. 146-148.

Alidibirov and Panov, 1998 M.A. Alidibirov and V. Panov, Magma fragmentation dynamics: experiments with analogue porous low-strength material, Bull. Volcanol. 59 (1998), pp. 481-489.

Andronico and Pistolesi, 2010 D. Andronico and M. Pistolesi, The November 2009 paroxysmal explosions at Stromboli, J. Volcanol. Geotherm. Res. 196 (2010), pp. 120-125.

Baldi et al., 2008 P. Baldi, M. Coltelli, M. Fabris, M. Marsella and P. Tommasi, High precision photogrammetry for monitoring the evolution of the NW flank of Stromboli volcano during and after the 2002-2003 eruption, Bull. Volcanol. 70 (2008), pp. 703-715.

Barberi et al., 1993 F. Barberi, M. Rosi and A. Sodi, Volcanic hazard assessment at Stromboli based on review of historical data, Acta Vulcanol. 3 (1993), pp. 173-187.

Bertagnini et al., 1999 A. Bertagnini, M. Coltelli, P. Landi, M. Pompilio and M. Rosi, Violent explosions yield new insights into dynamics of Stromboli volcano, Eos, Am. Geophys. Union Trans. 80 (1999), pp. 633-636.

Bertagnini et al., 2003 A. Bertagnini, N. Métrich, P. Landi and M. Rosi, Stromboli volcano (Aeolian Archipelago, Italy): an open window on the deep-feeding system of a steady state basaltic volcano, J. Geophys. Res. 108 (2003), p. 2336

Bonaccorso and Davis, 1999 A. Bonaccorso and P.M. Davis, Models of round deformation from vertical volcanic conduits with application to eruptions of Mount St. Helens and Mount Etna, J. Geophys. Res. 104 (1999), pp. 1053110542.

Bonaccorso et al., 2003 A. Bonaccorso, S. Calvari, G. Garfi, L. Lodato and D. Patané, Dynamics of the December 2002 flank failure and tsunami at Stromboli volcano inferred by volcanological and geophysical observations, Geophys. Res. Lett. 30 (2003), pp. 1941-1944.

Bonaccorso et al., 2008 A. Bonaccorso, S. Gambino, F. Guglielmino, M. Mattia, G. Puglisi and E. Boschi, Stromboli 2007 eruption: deflation modeling to infer shallow-intermediate plumbing system, Geophys. Res. Lett. 35 (2008), p. L06311

Bonaccorso et al., 2009 A. Bonaccorso, A. Bonforte, S. Gambino, M. Mattia, F. Guglielmino, G. Puglisi and E. Boschi, Insight on recent Stromboli eruption inferred from terrestrial and satellite ground deformation measurements, $J$. Volcanol. Geotherm. Res. 182 (2009), pp. 172-181. 
Burton et al., 2007 M.R. Burton, P. Allard, F. Muré and A. La Spina, Magmatic gas composition reveals the source depth of slug-driven Strombolian explosive activity, Science $\mathbf{3 1 7}$ (2007), pp. 227-230.

Burton et al., 2008 M.R. Burton, S. Calvari, L. Spampinato, L. Lodato, N.A. Pino, E. Marchetti and F. Muré, Volcanic and seismic activity at Stromboli preceding the 2002-03 flank eruption. In: S. Calvari, S. Inguaggiato, G. Puglisi, M. Ripepe and M. Rosi, Editors, The Stromboli Volcano: An Integrated Study of the 2002-2003 Eruption, AGU Monograph series 182 (2008), pp. 93-104.

Burton et al., 2009 M.R. Burton, T. Caltabiano, F. Murè, G. Salerno and D. Randazzo, $\mathrm{SO}_{2}$ flux from Stromboli during the 2007 eruption: results from the FLAME network and traverse measurements, J. Volcanol. Geotherm. Res. 182 (2009), pp. 214-220.

Calvari and Pinkerton, 1998 S. Calvari and H. Pinkerton, Formation of lava tubes and extensive flow field during the 1991-93 eruption of Mount Etna, J. Geophys. Res. 103 (1998), pp. 27291-27302.

Calvari et al., 2005a S. Calvari, L. Spampinato, L. Lodato, A.J.L. Harris, M.R. Patrick, J. Dehn, M.R. Burton and D. Andronico, Chronology and complex volcanic processes during the 2002-2003 flank eruption at Stromboli volcano (Italy) reconstructed from direct observations and surveys with a hand-held thermal camera, J. Geophys. Res. 110 (2005), p. B02201

Calvari et al., 2005b S. Calvari, L. Spampinato, L. Lodato, A.J.L. Harris, M.R. Patrick, J. Dehn, M.R. Burton and D. Andronico, Correction to "Chronology and complex volcanic processes during the 2002-2003 flank eruption at Stromboli volcano (Italy) reconstructed from direct observations and surveys with a handheld thermal camera", J. Geophys. Res. 110 (2005), p. B02201

Calvari et al., 2006 S. Calvari, L. Spampinato and L. Lodato, The 5 April 2003 vulcanian paroxysmal explosion at Stromboli volcano (Italy) from field observations and thermal data, J. Volcanol. Geotherm. Res. 149 (2006), pp. 160-175.

Calvari et al., 2010 S. Calvari, L. Lodato, A. Steffke, A. Cristaldi, A.J.L. Harris, L. Spampinato and E. Boschi, The 2007 Stromboli flank eruption: chronology of the events, and effusion rate measurements from thermal images and satellite data, J. Geophys. Res. 115 (B4) (2010), p. B04201

Di Carlo et al., 2006 I. Di Carlo, M. Pichavant, S. Rotolo and B. Scaillet, Experimental crystallization of a High-K Arc Basalt: the Golden Pumice, Stromboli Volcano (Italy), J. Petrol. 47 (2006), pp. 1317-1343.

Fornaciai et al., 2009 A. Fornaciai, M. Bisson, P. Landi, F. Mazzarini and M.T. Pareschi, A LiDAR survey of Stromboli volcano (Italy): digital elevation model- 
based geomorphology and intensità analysis, Int. J. Remote Sens. 31 (2009), pp. 3177-3194.

Francalanci et al., 2005 L. Francalanci, G.R. Davies, W. Lustenhouwer, S. Tommasini, P.R.D. Mason and S. Ponticelli, Intra-grain Sr isotope evidencefor crystal recycling and multiple magma reservoir in the recent activity of Stromboli volcano, Southern Italy, J. Petrol. 46 (2005), pp. 1997-2021.

Genco and Ripepe, 2010 R. Genco and M. Ripepe, Inflation-deflation cycles revealed by tilt and seismic records at Stromboli volcano, Geophys. Res. Lett. 37 (2010), p. L12302

Giberti et al., 1992 G. Giberti, C. Jaupart and G. Sartoris, Steady-state operation of Stromboli volcano, Italy: constraints on the feeding system, Bull. Volcanol. 54 (1992), pp. 535-541

Harris et al., 2005 A.J.L. Harris, J. Dehn, M.R. Patrick, S. Calvari, M. Ripepe and L. Lodato, Lava effusion rates from hand-held thermal infrared imagery: an example from the June 2003 effusive activity at Stromboli, Bull. Volcanol. 68 (2005), pp. 107-117.

Harris et al., 2007 A.J.L. Harris, J. Dehn and S. Calvari, Lava effusion rate definition and measurement: a review, Bull. Volcanol. 70 (2007), pp. 1-22.

Harris et al., 2008 A.J.L. Harris, M. Ripepe, S. Calvari, L. Lodato and L. Spampinato, The 5 April 2003 explosion of Stromboli: timing of eruption dynamics using thermal data. In: S. Calvari, S. Inguaggiato, G. Puglisi, M. Ripepe and M. Rosi, Editors, The Stromboli Volcano: An Integrated Study of the 2002-2003 Eruption, American Geophysical Union Monograph Series 182 (2008), pp. 305-316.

Hazlett et al., 1991 R.W. Hazlett, D. Buesch, J.L. Anderson, R. Elan and R. Scandone, Geology, failure conditions, and implications of seismogenic avalanches of the 1944 eruption at Vesuvius, Italy, J. Volcanol. Geotherm. Res. 47 (1991), pp. 249-264.

Ichihara et al., 2002 M. Ichihara, D. Rittel and B. Sturtevant, Fragmentation of a porous viscoelastic material: implications to magma fragmentation, $J$. Geophys. Res. 106 (2002), pp. 2226-2239.

Jaupart and Vergniolle, 1988 C. Jaupart and S. Vergniolle, Laboratory models of Hawaiian and Strombolian eruptions, Nature 331 (1988), pp. 58-60.

Kilburn, 1993 C.R.J. Kilburn, Lava crust, aa flow lengthening and the pahoehoe-aa transition. In: C.R.J. Kilburn and G. Luongo, Editors, Active Lavas: Monitoring and Modelling, UCL Press, London (1993), pp. 263-279. 
Kilburn and Lopes, 1988 C.R.J. Kilburn and R.M.C. Lopes, The growth of aa lava flow fields on Mount Etna, Sicily, J. Geophys. Res. 93 (B12) (1988), pp. 14759-14772.

Landi et al., 2009 P. Landi, R.A. Corsaro, L. Francalanci, L. Civetta, L. Miraglia, M. Pompilio and R. Tesoro, Magma dynamics during the 2007 Stromboli eruption (Aeolian Islands, Italy): mineralogical, geochemical and isotopic data, J. Volcanol. Geotherm. Res. 182 (2009), pp. 255-268.

Lautze and Houghton, 2007 N.C. Lautze and B.F. Houghton, Linking variable explosion style and magma textures during 2002 at Stromboli volcano, Italy, Bull. Volcanol. 69 (2007), pp. 445-460.

Lodato et al., 2007 L. Lodato, L. Spampinato, A.J.L. Harris, S. Calvari, J. Dehn and M.R. Patrick, The morphology and evolution of the Stromboli 2002-03 lava flow field: an example of a basaltic flow field emplaced on a steep slope, Bull. Volcanol. 69 (2007), pp. 661-679.

Lombardo et al., 2009 V. Lombardo, A.J.L. Harris, S. Calvari and M.F. Buongiorno, Spatial variations in lava flow field thermal structure and effusion rate derived from very high spatial resolution hyperspectral (MIVIS) data, J. Geophys. Res. 114 (2009), p. B02208

Lyons et al., 2010 J.J. Lyons, G.P. Waite, W.I. Rose and G. Chigna, Patterns in open vent, strombolian behavior at Fuego volcano, Guatemala, 2005-2007, Bull. Volcanol. 72 (2010), pp. 1-15.

Martel et al., 2000 C. Martel, D.B. Dingwell, O. Spieler, M. Pichavant and M. Wilke, Fragmentation of foamed silicic melts: an experimental study, Earth Planet. Sci. Lett. 178 (2000), pp. 47-58.

Métrich et al., 2005 N. Métrich, A. Bertagnini, P. Landi, M. Rosi and O. Belhadj, Triggering mechanism at the origin of paroxysms at Stromboli (Aeolian Archipelago, Italy): the 5 April 2003 eruption, Geophys. Res. Lett. 32 (2005), p. L10305

Namiki and Manga, 2006 A. Namiki and M. Manga, Influence of decompression rate on the expansion velocity and expansion style of bubbly fluids, J. Geophys. Res. B11208 (2006), p. 111

Neri and Lanzafame, 2009 M. Neri and G. Lanzafame, Structural features of the 2007 Stromboli eruption, J. Volcanol. Geotherm. Res. 182 (2009), pp. 137144

Perret, 1916 F.A. Perret, The lava eruption of Stromboli summer-autumn, 1915, Am. J. Sci. 42 (1916), pp. 436-457. 
Pichavant et al., 2009 M. Pichavant, I. Di Carlo, Y. Le Gac, S.G. Rotolo and B. Scaillet, Experimental constraints on the deep magma feeding system at Stromboli volcano, Italy, J. Petrol. $\mathbf{5 0}$ (2009), pp. 601-624.

Polacci et al., 2009 M. Polacci, D.R. Baker, L. Mancini, S. Favretto and R.J. Hill, Vesiculation in magmas from Stromboli and implications for normal Strombolian activity and paroxysmal explosions in basaltic systems, J. Geophys. Res. 114 (2009), p. B01206

Poland et al., 2009 M.P. Poland, A.J. Sutton and T.M. Gerlach, Magma degassing triggered by static decompression at Kilavea Volcano, Hawai'i, Geophys. Res. Lett. 36 (2009), p. L16306

Rittmann, 1931 A. Rittmann, Der ausbruch des Stromboli am 11 September 1930, Z. vulkanol. 14 (1931), pp. 47-77.

Rosi et al., 2000 M. Rosi, A. Bertagnini and P. Landi, Onset of the persistent activity at Stromboli Volcano (Italy), Bull. Volcanol. 62 (2000), pp. 294-300.

Schiavi et al., 2010 F. Schiavi, K. Kobayashi, T. Moriguti, E. Nakamura, M. Pompilio, M. Tiepolo and R. Vannucci, Degassing, crystallization and eruption dynamics at Stromboli: trace element and lithium isotopic evidence from 2003 ashes, Contrib. Mineral. Petrol. 159 (2010), pp. 541-561.

Spampinato et al., 2008 L. Spampinato, S. Calvari, A.J.L. Harris and J. Dehn, Evolution of the lava flow field. In: S. Calvari, S. Inguaggiato, G. Puglisi, M. Ripepe and M. Rosi, Editors, The Stromboli Volcano: An Integrated Study of the 2002-2003 Eruption, American Geophysical Union Monograph Series 182 (2008), pp. 201-212.

Spieler et al., 2004 O. Spieler, B. Kennedy, U. Kueppers, D.B. Dingwell, B. Scheu and J. Taddeucci, The fragmentation threshold of pyroclastic rocks, Earth Planet. Sci. Lett. 226 (2004), pp. 139-148.

Walker, 1973 G.P.L. Walker, Lengths of lava flows, Philos. Trans. R. Soc. London 274 (1238) (1973), pp. 107-1 16.

Wilson, 1980 L. Wilson, Relationships between pressure, volatile content and ejecta velocity in three types of volcanic explosions, J. Volcanol. Geotherm. Res. 8 (1980), pp. 297-313. 
Figures 


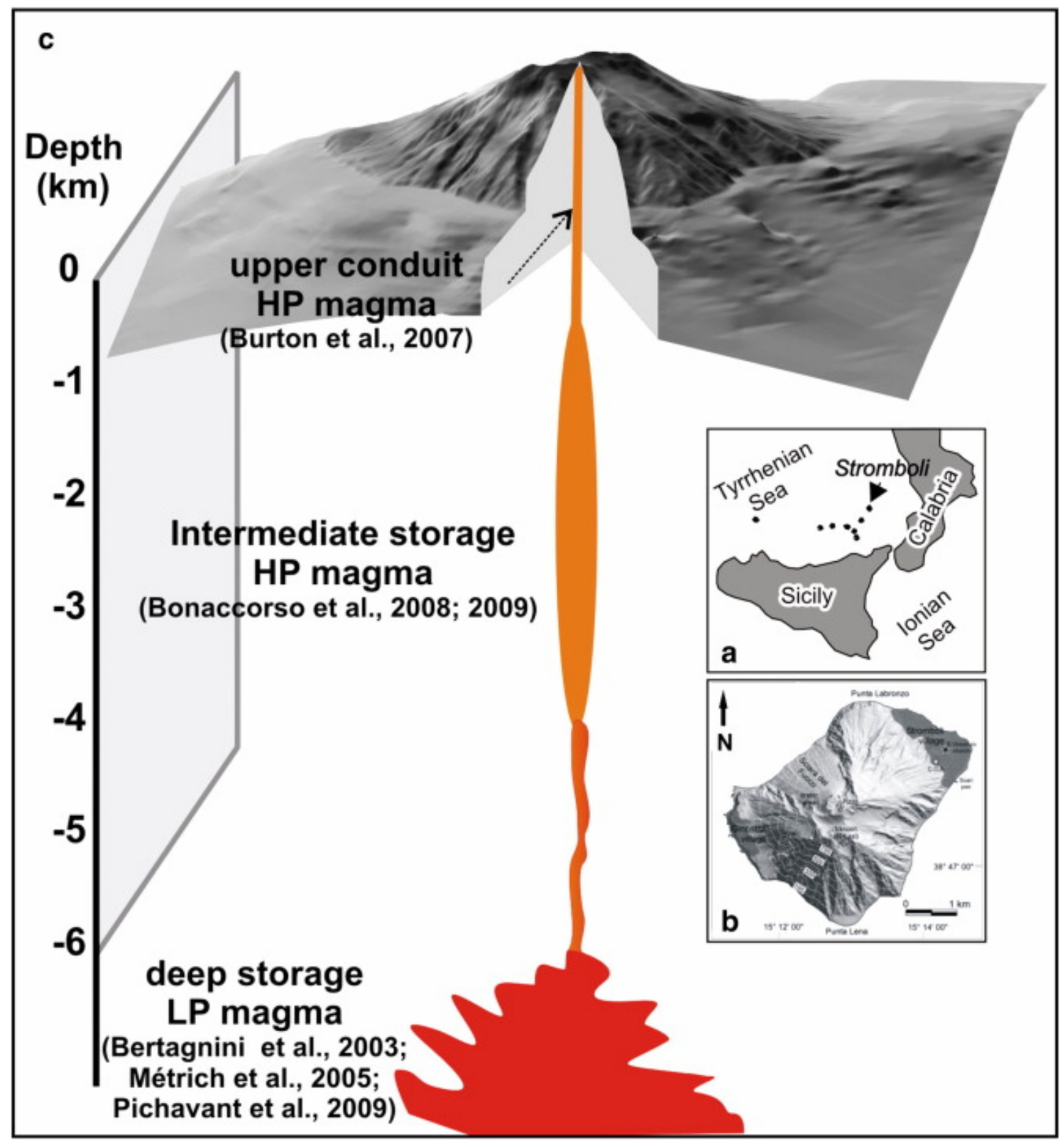

Fig. 1. : (a) Aeolian Islands and position of Stromboli in the southern Tyrrhenian Sea. (b) Map of Stromboli island. (c) Simplified section of Stromboli feeding system, showing the upper conduit extending from the magma surface $(750 \mathrm{~m}$ a.s.l. corresponding to the elevation of the summit craters) to $\sim 2 \mathrm{~km}$ b.s.l. (Burton et al., 2007), and the intermediate storage system (2-4 km depth; [Bonaccorso et al., 2008] and [Bonaccorso et al., 2009]). These both contain HP magma, whereas the deep magma storage zone, below $6 \mathrm{~km}$ depth, contains LP magma (e.g., [Bertagnini et al., 2003], [Métrich et al., 2005] and [Pichavant et al., 2009]). 

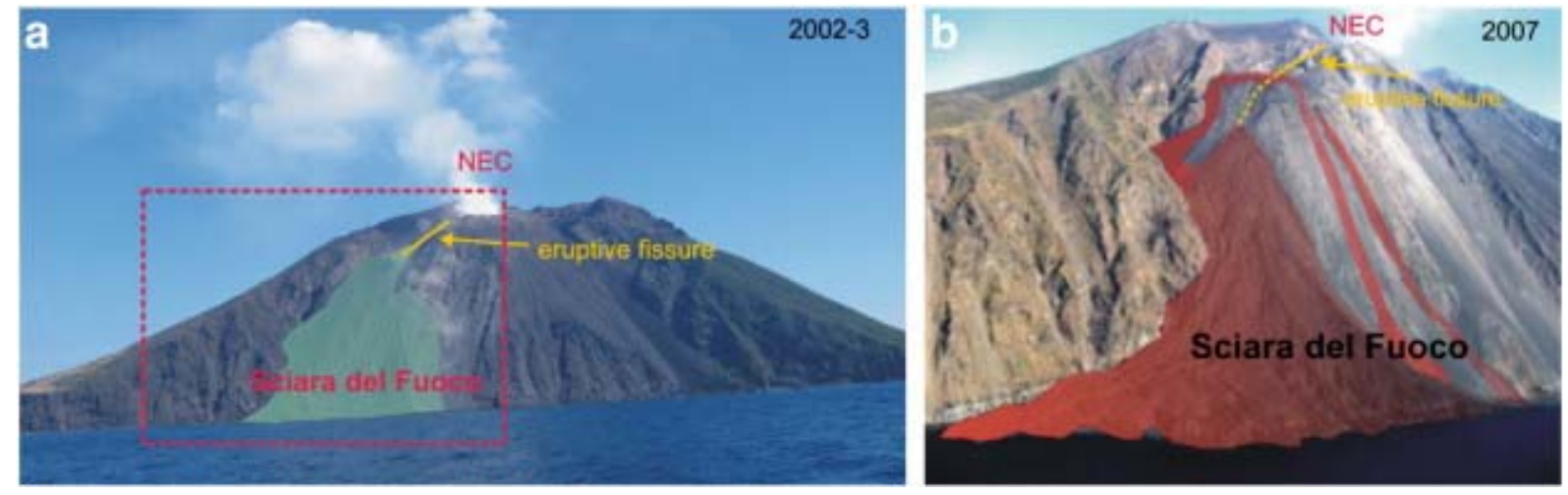

Fig. 2. : (a) Photograph of Stromboli island taken from the north on 8 April 2003, showing the Sciara del Fuoco, the north-east summit crater (NEC), the 2002-2003 eruptive fissure (in yellow) and lava flow field (in green). The red dotted square indicates the area shown in $b$. (b) Photograph of the Sciara del Fuoco taken from the north on 16 July 2007, showing the NEC, the 2007 eruptive fissure (in yellow) and lava flow field (in red).

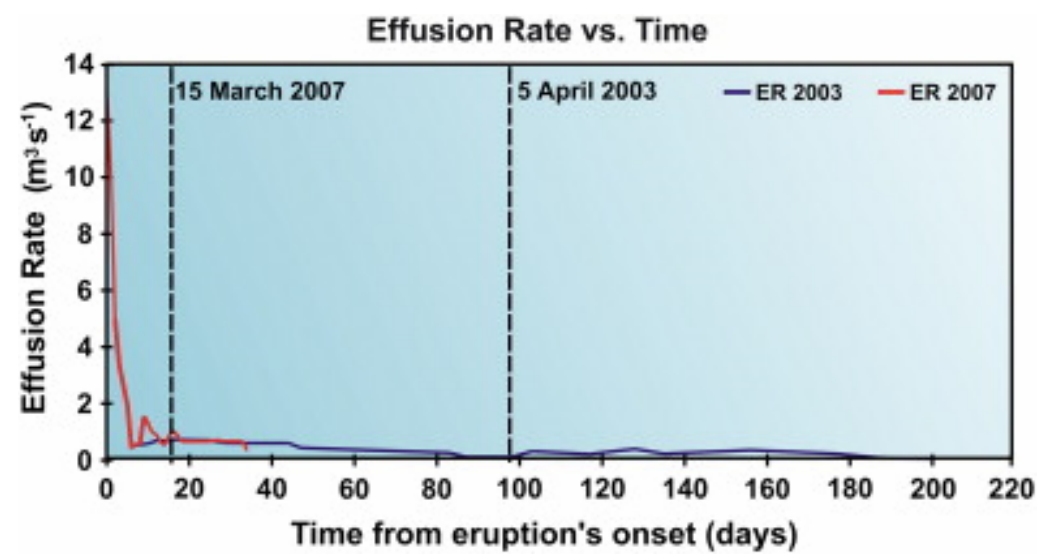

Fig. 3. Comparison of the effusion rates $\left(\mathrm{m}^{3} \mathrm{~s}^{-1}\right)$ measured during the 2002-2003 ([Calvari et al., 2005a], [Calvari et al., 2005b] and [Lodato et al., 2007]) and the 2007 (Calvari et al., 2010) eruptions vs. time (days) from eruption's onset. Note that for both eruptions effusion rate values are here reported as 7-day-moving averages. 


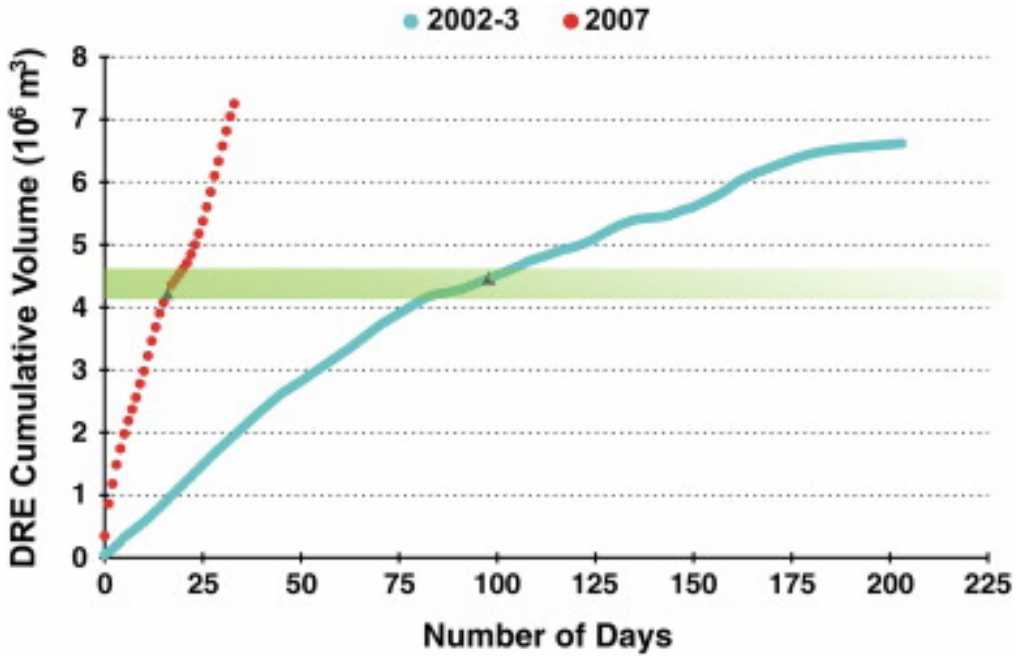

Fig. 4. Graph of the cumulative DRE volumes of erupted lava for both the 2002-2003 (blue line) and 2007 (red dots) vs. time since the eruption onset. In both time-series, the green triangles indicate the cumulative volumes of lava emitted by 5 April $2003\left(4.4 \times 10^{6} \mathrm{~m}^{3}\right)$ and 15 March $2007\left(4.2 \times 10^{6} \mathrm{~m}^{3}\right)$, i.e., the dates of paroxysms. The green band highlights the similarity of the two cumulative volumes. Data recalculated after [Calvari et al., 2005a], [Calvari et al., 2005b], [Calvari et al., 2010], [Harris et al., 2005] and [Lodato et al., 2007]. 

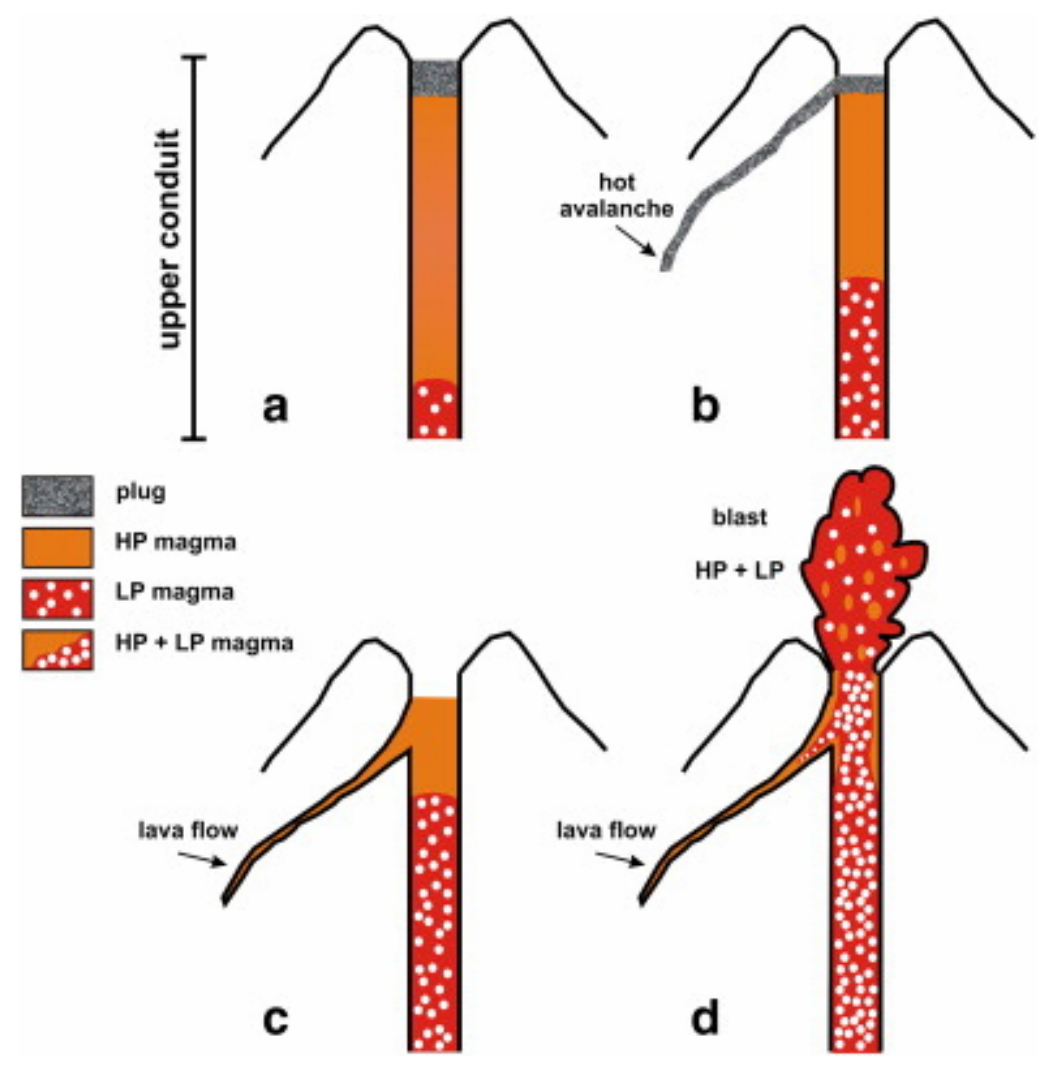

Fig. 5. Sketch showing the upper conduit of Stromboli, with phases of less-porphyritic (LP) magma rising, and its relationships with the high-porphyricity (HP) magma. (a) The upper conduit before the onset of an effusive eruption. (b) The plug removed during the initial phases of an effusive eruption (crater breaching and hot avalanche spreading). (c) Effusive vent opening and lava flow draining the upper, HP magma column. (d) LP magma erupting explosively (paroxysm) and being drained through the effusive vent, mixing with the HP magma. 


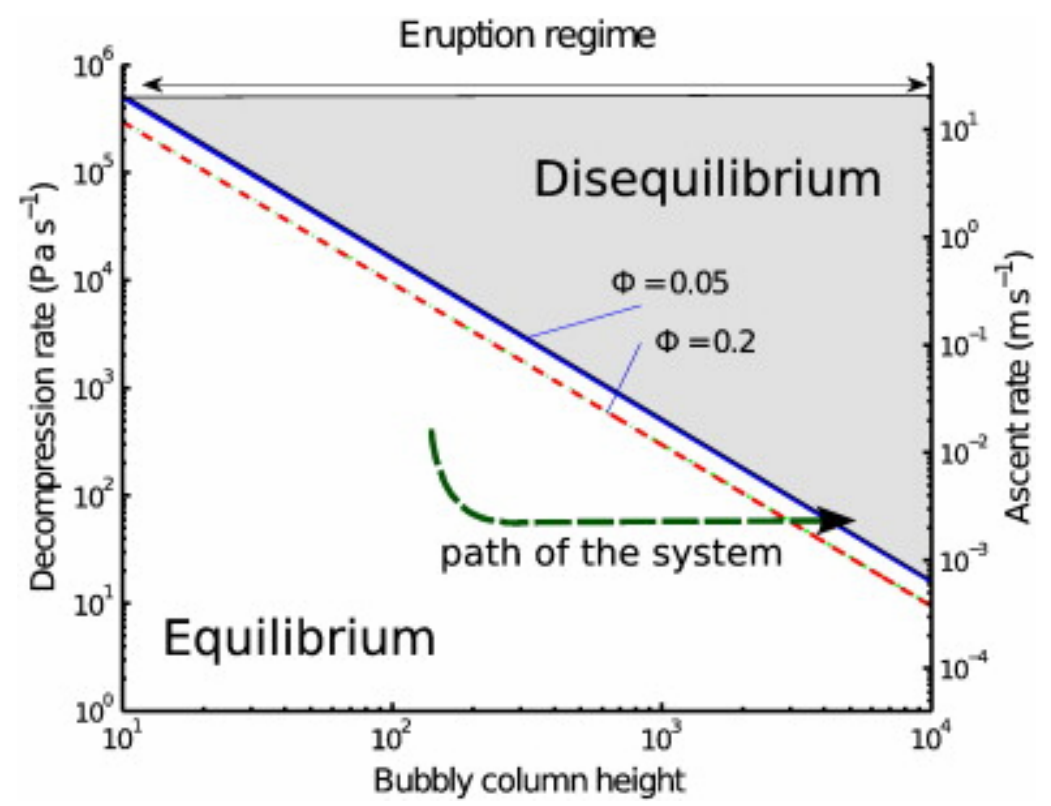

Fig. 6. Eruption regime as a function of decompression rate and height of the bubbly magma column. The solid and the dashed lines correspond to vesicularity of $\Phi=0.05$, and $\Phi=0.2$, respectively. The grey area represents the space of parameters where disequilibrium expansion, and possibly fragmentation, is favoured. After a fast initial eruptive phase, the rate of lava emission in 2003 and 2007 stabilises around $1 \mathrm{~m}^{3} \mathrm{~s}^{-1}$, meaning that more volatile-rich LP magma volumes from the deeper storage system ascend with velocity of about $3 \mathrm{~mm} \mathrm{~s}^{-1}$, equivalent to a decompression rate of $\sim 90 \mathrm{~Pa} \mathrm{~s}^{-1}$ (a conduit radius of $10 \mathrm{~m}$ and magma density $\rho=2500 \mathrm{~kg} \mathrm{~m}^{-3}$ are assumed in this calculation). If this decompressed magma vesiculates, then the height of the bubbly magma column increases until a threshold is overcome (green arrow) and the system experiences disequilibrium expansion. After Namiki and Manga (2006), (see equation 1 in our text), using the pressure of the gas outside the bubbles during the expansion at $\mathrm{POt}_{\mathrm{O}}=10^{5} \mathrm{~Pa}$ (atmospheric pressure), and the initial pressure of the gas inside the bubbles $P_{G i}=\rho g h(1-\Phi)$. 
Table 1. Catalogue of paroxysms at Stromboli over the last century, based on Barberi et al. (1993). Several occurred in association with effusive eruptions, including the 2002-2003 and 2007 eruptions.

\begin{tabular}{|c|c|c|c|c|}
\hline $\begin{array}{l}\text { Date of } \\
\text { paroxysms }\end{array}$ & Effects & Notes & $\begin{array}{l}\text { Total enupted } \\
\text { lava volume } \\
\left(\mathbf{m}^{3}\right)\end{array}$ & References \\
\hline $\begin{array}{l}11-16 \text { July } \\
1906\end{array}$ & Hot avalanche, vegetation ignited & & & Barberi et al., 1993 \\
\hline 27 April 1907 & $\begin{array}{l}\text { Ash fall up to Messina, acid rain, houses damaged } \\
\text { by air shock }\end{array}$ & & & Barberi et al., 1993 \\
\hline 4 July 1916 & $\begin{array}{l}\text { Fallout of ash, bombs and scoriae, vegetation } \\
\text { ignited }\end{array}$ & & & Barberi et al., 1993 \\
\hline 22 May 1919 & $\begin{array}{l}1000 \mathrm{~kg} \text { bombs fell on the village of Stromboli; } 4 \\
\text { deaths; } 20 \text { injured }\end{array}$ & & & Barberi et al., 1993 \\
\hline $\begin{array}{l}22 \text { October } \\
1930\end{array}$ & Lava fountains, vegetation ignited & $\begin{array}{l}\text { Paroxysm } \\
\text { during lava }\end{array}$ & & Barberi et al., 1993 \\
\hline
\end{tabular}




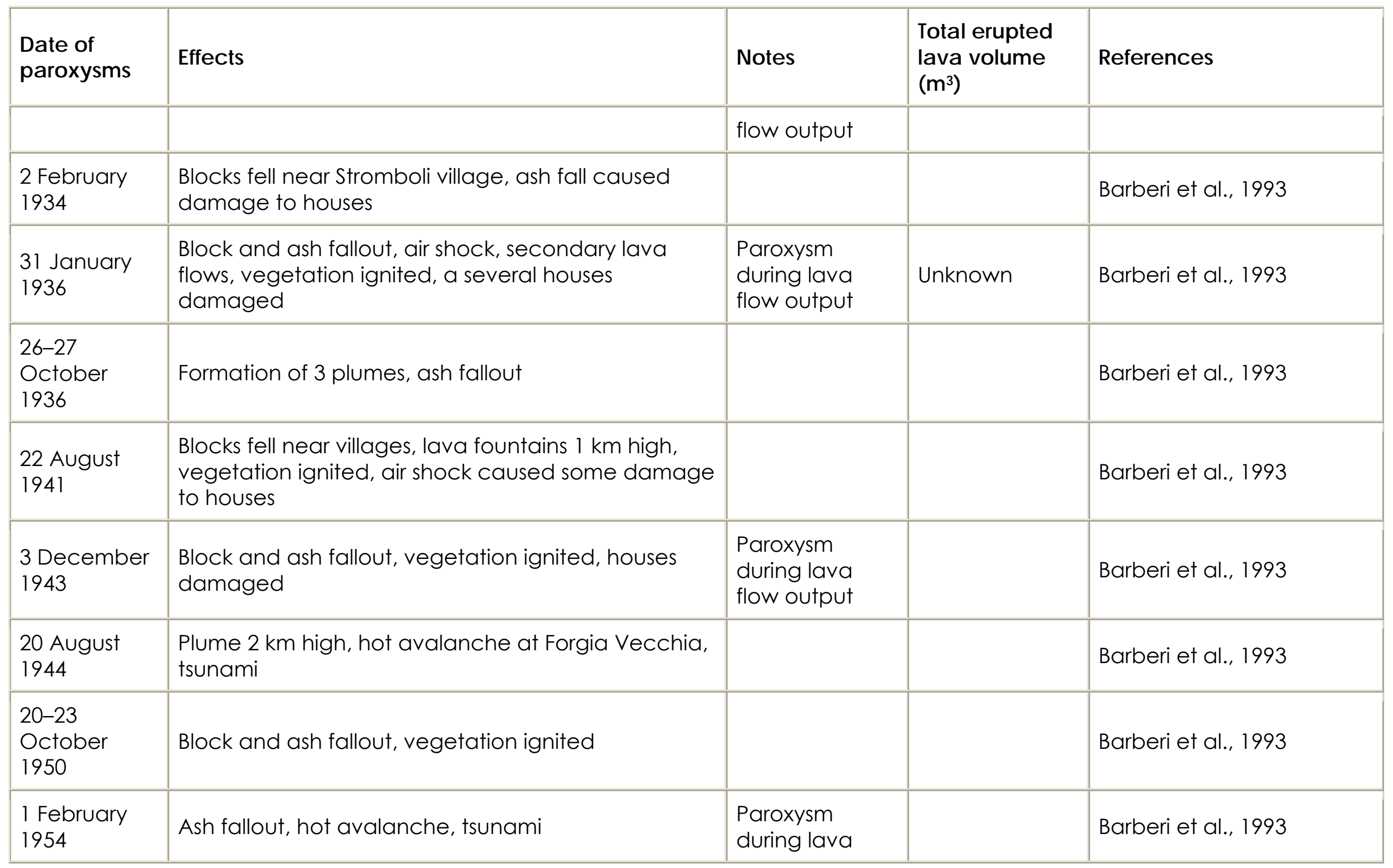




\begin{tabular}{|c|c|c|c|c|}
\hline $\begin{array}{l}\text { Date of } \\
\text { paroxysms }\end{array}$ & Effects & Notes & $\begin{array}{l}\text { Total enupted } \\
\text { lava volume } \\
\left(\mathrm{m}^{3}\right)\end{array}$ & References \\
\hline 5 April 2003 & $\begin{array}{l}\text { Plume } 2 \mathrm{~km} \text { high, pyroclastic flows, houses } \\
\text { damaged at Ginostra }\end{array}$ & $\begin{array}{l}\text { Paroxysm } \\
\text { during lava } \\
\text { flow output }\end{array}$ & $\sim 13 \times 10^{6}$ & $\begin{array}{l}\text { [Calvari et al., 2005a], } \\
\text { [Calvari et al., 2005b] and } \\
\text { [Calvari et al., 2006] }\end{array}$ \\
\hline
\end{tabular}

